\title{
KONSTITUSIONALITAS UNDANG-UNDANG PELAYARAN
}

\author{
(Constitutionality Of Sailing Law)
}

\author{
Luthfi Widagdo Eddyono \\ Pusat Penelitian dan Pengkajian Perkara, dan Pengelolaan Perpustakaan \\ Mahkamah Konstitusi Republik Indonesia \\ Jalan Medan Merdeka Barat Nomor 6, Jakarta Pusat \\ Email: luthfi_we@yahoo.com
}

Naskah diterima: 28 Juni 2019; revisi: 25 Juli 2019; disetujui: 2 Agustus 2019

\begin{abstract}
Abstrak
Hingga kini Undang-Undang Nomor 17 Tahun 2008 tentang Pelayaran (UU Pelayaran) merupakan salah satu undang-undang yang paling sedikit di uji oleh Mahkamah Konstitusi. Tercatat tiga permohonan telah diajukan ke Mahkamah Konstitusi. Hasilnya, dua perkara yaitu 65/PUU-XII/2014 dan 64/PUU-XIII/2015 tidak dapat diterima, dan satu perkara, yaitu perkara Nomor 74/PUU-VIII/2010 ditolak. Tulisan ini akan menjawab pertanyaan terkait konstitusionalitas UU Pelayaran dengan melakukan kajian terhadap putusan yang ditolak saja, yaitu pada perkara 74/PUU-VIII/2010 mengingat putusan yang menyatakan permohonan tidak dapat diterima pada prinsipnya merupakan penolakan gugatan di luar pokok perkara/ permohonan. Tulisan ini merupakan penelitian hukum normatif dengan cara meneliti bahan hukum primer yaitu putusan Mahkamah Konstitusi dan bahan pustaka lainnya sebagai bahan sekunder. Kesimpulannya, putusan tersebut menjadi penting dalam pengembangan hukum maritim karena terdapat penegasan pemaknaan atas diskriminasi dalam konteks hukum, termasuk dalam kaitannya dengan hukum maritim. Mahkamah Konstitusi juga secara tegas membatasi dirinya untuk melakukan aktivisme yudisial (judicial activism) terhadap norma yang bersifat kebijakan hukum terbuka (open legal policy) di bidang pelayaran dan maritim. Mahkamah Konstitusi malah melakukan pembatasan yudisial (judicial restraint) dan berhati-hati untuk tidak masuk ke ranah pembentukan hukum dalam UU Pelayaran. Terakhir, Mahkamah Konstitusi menjawab tudingan monopoli dalam UU Pelayaran dan nilai-nilai ekonomis maritim lainnya.
\end{abstract}

Kata Kunci: pelayaran, Mahkamah Konstitusi, pembatasan yudisial

\begin{abstract}
Until now, Law Number 17 of 2008 concerning Shipping (the Shipping Law) is one of the least tested by the Constitutional Court. Recorded three requests have been submitted to the Constitutional Court. As a result, two cases, 65/PUU-XII/2014 and 64/PUU-XIII/2015 were not acceptable, and one case, namely case Number 74/PUU-VIII/2010 was rejected. This paper will answer questions related to the constitutionality of the Shipping Law by conducting a study of only rejected decisions, namely in case 74/PUU-VIII/2010 considering the decision stating that the application is unacceptable in principle is a rejection of the claim outside the case/petition. This paper is a normative legal research by examining primary legal materials, namely the Constitutional Court's decision and other library materials as secondary material. In conclusion, the decision is important in the development of maritime law because there is an affirmation of the meaning of discrimination in a legal context, including in relation to maritime law. The Constitutional Court also expressly limits itself to judicial activism towards norms that are open legal policies in the shipping and maritime fields. The Constitutional Court even imposed judicial restraint and was careful not to enter into the realm of legal formation in the Shipping Law. Finally, the Constitutional Court answers the monopoly accusations in the Shipping Law and other maritime economic values. Keywords: sailing, Constitutional Court, judicial restraint
\end{abstract}




\section{A. Pendahuluan}

Undang-Undang Nomor 17 Tahun 2008 tentang Pelayaran (UU Pelayaran) merupakan salah satu undang-undang yang sangat penting dalam mengatur kondisi maritim Indonesia. Sebagai negara kepulauan, Indonesia dikatakan berciri nusantara karena disatukan oleh wilayah perairan sangat luas dengan batas-batas, hak-hak, dan kedaulatan yang ditetapkan dengan undang-undang. UU Pelayaran diharapkan mewujudkan wawasan nusantara serta memantapkan ketahanan nasional diperlukan sistem transportasi nasional untuk mendukung pertumbuhan ekonomi, pengembangan wilayah, dan memperkukuh kedaulatan negara. ${ }^{1}$

Berdasarkan Bagian Menimbang UU Pelayaran, dikatakan bahwa pelayaran yang terdiri atas angkutan di perairan, kepelabuhanan, keselamatan dan keamanan pelayaran, dan perlindungan lingkungan maritim, merupakan bagian dari sistem transportasi nasional yang harus dikembangkan potensi dan peranannya untuk mewujudkan sistem transportasi yang efektif dan efisien, serta membantu terciptanya pola distribusi nasional yang mantap dan dinamis.

\section{"Perkembangan lingkungan strategis} nasional dan internasional menuntut penyelenggaraan pelayaran yang sesuai dengan perkembangan ilmu pengetahuan dan teknologi, peran serta swasta dan persaingan usaha, otonomi daerah, dan akuntabilitas penyelenggara negara, dengan tetap mengutamakan keselamatan dan keamanan pelayaran demi kepentingan nasional." ${ }^{2}$

Sebelumnya, untuk mengatur pelayaran, sudah ada Undang-Undang Nomor 21 Tahun 1992 tentang Pelayaran. Akan tetapi, norma dalam undang-undang tersebut dianggap sudah tidak sesuai lagi dengan kebutuhan penyelenggaraan pelayaran saat ini sehingga perlu diganti dengan undang-undang yang baru. ${ }^{3}$

"Dalam perjalanan waktu, Undang-Undang Nomor 21 Tahun 1992 tentang Pelayaran perlu dilakukan penyesuaian karena telah terjadi berbagai perubahan paradigma dan lingkungan strategis, baik dalam sistem ketatanegaraan Indonesia seperti penerapan otonomi daerah atau adanya kemajuan di bidang ilmu pengetahuan dan teknologi. Selain itu, pengertian istilah "pelayaran" sebagai sebuah sistem pun telah berubah dan terdiri dari angkutan di perairan, kepelabuhanan, keselamatan dan keamanan pelayaran, serta perlindungan lingkungan maritim, yang selanjutnya memerlukan penyesuaian dengan kebutuhan dan perkembangan zaman serta ilmu pengetahuan dan teknologi agar dunia pelayaran dapat berperan di dunia internasional." ${ }^{4}$

\footnotetext{
Baca lebih lanjut Undang-Undang Nomor 17 Tahun 2008 tentang Pelayaran, Lembaran Negara Republik Indonesia Tahun 2008 Nomor 64, Tambahan Lembaran Negara Republik Indonesia Nomor 4849.[ http:// mahpel.dephub.go.id/_uploads/peraturan/a64fc7d7c223ff44d471ba8ea1efd516.pdf], diakses 1 April 2019.

2 Ibid.

3 Dengan diundangkannya UU Pelayaran 2008 tersebut, berbagai ketentuan yang terdapat dalam peraturan perundang-undangan lain yang berkaitan dengan pelayaran, antara lain Kitab Undang-Undang Hukum Dagang (Wet Borepublikek Van Koophandel), Ordonansi Laut Teritorial dan Lingkungan Maritim Tahun 1939, Undang-Undang Nomor 1 Tahun 1973 tentang Landas Kontinen Indonesia, Undang-Undang Nomor 5 Tahun 1983 tentang Zona Ekonomi Eksklusif Indonesia, Undang-Undang Nomor 17 Tahun 1985 tentang Pengesahan Konvensi Perserikatan Bangsa-Bangsa tentang Hukum Laut 1982 (United Nations Convention on the Law of the Sea, 1982), Undang-Undang Nomor 6 Tahun 1996 tentang Perairan Indonesia, Undang-Undang Nomor 23 Tahun 1997 tentang Pengelolaan Lingkungan Hidup, Undang-Undang Nomor 31 Tahun 2004 tentang Perikanan, dan sepanjang menyangkut aspek keselamatan dan keamanan pelayaran dinyatakan tunduk pada pengaturan UU ini. Ibid.

4 Baca Bagian Penjelasan Umum Undang-Undang Nomor 17 Tahun 2008 tentang Pelayaran. Ibid.
} 
Secara umum, UU Pelayaran memuat empat unsur utama yakni angkutan di perairan, kepelabuhanan, keselamatan dan keamanan pelayaran, serta perlindungan lingkungan maritim yang dapat diuraikan, yaitu:

a. Pengaturan untuk bidang angkutan di perairan memuat prinsip pelaksanaan asas cabotage dengan cara pemberdayaan angkutan laut nasional yang memberikan iklim kondusif guna memajukan industri angkutan di perairan, antara lain adanya kemudahan di bidang perpajakan, dan permodalan dalam pengadaan kapal serta adanya kontrak jangka panjang untuk angkutan. Dalam rangka pemberdayaan industri angkutan laut nasional, dalam undang-undang ini diatur pula mengenai hipotek kapal. Pengaturan ini merupakan salah satu upaya untuk meyakinkan kreditor bahwa kapal Indonesia dapat dijadikan agunan berdasarkan peraturan perundang-undangan, sehingga diharapkan perusahaan angkutan laut nasional akan mudah memperoleh dana untuk pengembangan armadanya;

b. Pengaturan untuk bidang kepelabuhanan memuat ketentuan mengenai penghapusan monopoli dalam penyelenggaraan pelabuhan, pemisahan antara fungsi regulator dan operator serta memberikan peran serta pemerintah daerah dan swasta secara proposional di dalam penyelenggaraan kepelabuhanan;

c. Pengaturan untuk bidang keselamatan dan keamanan pelayaran memuat ketentuan yang mengantisipasi kemajuan teknologi dengan mengacu pada konvensi internasional yang cenderung menggunakan peralatan mutakhir pada sarana dan prasarana keselamatan pelayaran, di samping mengakomodasi ketentuan mengenai sistem keamanan pelayaran yang termuat dalam "International Ship and Port Facility Security Code"; dan

d. Pengaturan untuk bidang perlindungan lingkungan maritim memuat ketentuan mengenai pencegahan dan penanggulangan pencemaran lingkungan laut yang bersumber dari pengoperasian kapal dan sarana sejenisnya dengan mengakomodasikan ketentuan internasional terkait seperti "International Convention for the Prevention of Pollution from Ships". ${ }^{5}$

Selain itu, dalam UU Pelayaran juga diatur secara tegas dan jelas pembentukan institusi di bidang penjagaan laut dan pantai (Sea and Coast Guard) yang dibentuk dan bertanggung jawab kepada Presiden dan secara teknis operasional dilaksanakan oleh Menteri. ${ }^{6}$

Ibid.

6 Tugas menjaga keamanan dan kegiatan operasi keamanan di laut semula dikerjakan oleh Badan Koordinasi Keamanan Laut (Bakorkamla) yang dibentuk berdasarkan Keputusan Bersama Menteri Pertahanan dan Keamanan/Panglima Angkatan Bersenjata, Menteri Perhubungan, Menteri keuangan, Menteri Kehakiman, dan Jaksa Agung Nomor KEP/B/45/XII/1972; SK/901/M/1972; KEP.779/MK/III/12/1972; J.S.8/72/1;KEP-085/ J.A/12/1972 tentang Pembentukan Badan Koordinasi Keamanan di Laut dan Komando Pelaksana Operasi Bersama Keamanan di Laut. Dalam rangka meningkatkan koordinasi antar berbagai instansi pemerintah di bidang keamanan laut, pada tahun 2003 melalui Keputusan Menteri Koordinator Bidang Politik dan Keamanan, Nomor Kep.05/Menko/Polkam/2/2003 dibentuk kelompok Kerja Perencanaan Pembangunan Keamanan dan Penegakan Hukum di Laut. Selanjutnya, pada 29 Desember 2005 ditetapkan Peraturan Presiden Nomor 81 Tahun 2005 tentang Badan Koordinasi Keamanan Laut (Bakorkamla) yang menjadi dasar hukum dari Badan 
UU Pelayaran ini memang menyebutkan hanya mengatur hal-hal yang bersifat pokok, sedangkan yang bersifat teknis dan operasional akan diatur dalam Peraturan Pemerintah dan peraturan pelaksanaan lainnya.

Dalam perkembangannya, UU Pelayaran ini sempat digugat hingga tiga kali ke Mahkamah Konstitusi. Tercatat tiga permohonan telah diajukan ke Mahkamah Konstitusi, yaitu dalam perkara 74/PUU-VIII/2010, 65/PUU-XII/2014, dan 64/PUU-XIII/2015. Hasilnya, dua perkara yaitu 65/PUU-XII/2014 dan 64/PUU-XIII/2015 tidak dapat diterima, dan satu perkara 74/ PUU-VIII/2010 ditolak. ${ }^{7}$

Tulisan ini bermaksud untuk menjawab pertanyaan terkait konstitusionalitas UU Pelayaran terkait kepastian hukum norma peraturan perundang-undangan. Tulisan ini akan melakukan analisis terhadap putusan yang ditolak saja, yaitu pada perkara 74/ PUU-VIII/2010 mengingat putusan yang menyatakan permohonan tidak dapat diterima (niet ontvankelijk verklaard) pada prinsipnya merupakan penolakan gugatan di luar pokok perkara/permohonan karena tidak dipenuhinya syarat-syarat formalitas dalam beracara di pengadilan, seperti kewenangan pengadilan, kedudukan hukum, dan lainnya, sedangkan permohonan ditolak berarti penolakan terhadap pokok permohonannya. ${ }^{8}$
Dua perkara yaitu perkara 65/PUU-XII/2014, dan 64/PUU-XIII/2015 merupakan perkara yang tidak diberikan pertimbangan terkait substansi perkaranya sehingga kajian terhadap Putusan Mahkamah Konstitusi terkait UU Pelayaran tidaklah relevan untuk dibuat. Selain itu, putusan yang ditolak oleh Mahkamah Konstitusi tidaklah berarti Putusan tersebut tidak penting. Putusan tersebut malah melegitimasikan norma dalam undang-undang yang diuji karena berarti konstitusionalitasnya diakui, ${ }^{9}$ sehingga kajian dan analisis sangat penting untuk putusan yang demikian untuk menegaskan konstitusionalitas UU Pelayaran.

\section{B. Metode Penelitian}

Penelitian ini merupakan penelitian hukum normatif dengan cara meneliti bahan hukum primer yaitu putusan Mahkamah Konstitusi khususnya dalam perkara 74/ PUU-VIII/2010 dan bahan pustaka lainnya sebagai bahan sekunder. ${ }^{10}$ Walau demikian, pembahasan secara deskriptif digunakan untuk menggambarkan perkara-perkara yang diajukan ke Mahkamah Konstitusi terkait hukum maritim dan UU Pelayaran, serta isu lainnya karena logika hukum yang digunakan oleh Mahkamah Konstitusi juga kerap diperlakukan secara umum dan konsisten.

Koordinasi Keamanan Laut. Hingga diterbitkannya Peraturan Presiden Nomor 178 Tahun 2014 tentang Badan Keamanan Laut, maka Bakorkamla telah berubah nama menjadi Bakamla dengan kewenangan yang lebih efektif dalam mengamankan laut di seluruh wilayah nusantara. [https://kominfo.go.id/index.php/content/ detail/4327/Presiden+Jokowi+Resmi+Bentuk+Badan+Keamanan+Laut/0/berita], diakses 05/07/2019.

7 Sistem Informasi Mahkamah Konstitusi dalam [http://simpp.mkri.go.id/index.php?page=web.CetakUndang Adv\&id=1\&aw=1\&ak=1\&t1=pelayaran\&t2=\&t3=\&op1=AND\&op2=AND\&jp1=h.undang_undang\&jp2=a.judul_ perkara\&jp3=a.judul_perkara\&jmln=0\&st=1], diakses 1 April 2019.

8 Luthfi Widagdo Eddyono, Memaknai Konstitusionalisme Indonesia, (Bandar Lampung: Aura Publishing, 2018).

9 Irfan Nur Rachman, Konstruksi Pseudo Judicial Review dalam Sengketa Hasil Pemilihan Kepala Daerah, Bandar Lampung: Aura Publishing, 2019).

10 Sarjono Soekanto dan Sri Mamudji, Penelitian Hukum Normatif, Suatu Tinjauan Singkat, (Jakarta: Rajawali Pers, 2008), hlm. 13-14. 
Lebih lanjut, hal-hal tersebut akan digunakan untuk menganalisis konstitusionalitas UU Pelayaran atau isu maritim lainnya jika diperhadapkan dengan UUD 1945.

\section{Pembahasan}

\section{Pengujian Undang-Undang oleh Mahkamah Konstitusi}

Pasal 24 ayat (2) UUD 1945 pasca reformasi menyatakan, kekuasaan kehakiman dilakukan oleh sebuah Mahkamah Agung dan badan peradilan yang berada di bawahnya dalam lingkungan peradilan umum, lingkungan peradilan agama, lingkungan peradilan militer, lingkungan peradilan tata usaha negara, dan oleh sebuah Mahkamah Konstitusi. Berdasarkan ketentuan tersebut, Mahkamah Konstitusi merupakan salah satu pelaku kekuasaan kehakiman selain Mahkamah Agung. Kekuasaan kehakiman merupakan kekuasaan yang merdeka untuk menyelenggarakan peradilan guna menegakkan hukum dan keadilan. Dengan demikian, Mahkamah Konstitusi adalah suatu lembaga peradilan, sebagai cabang kekuasaan yudikatif, yang mengadili perkara-perkara tertentu yang menjadi kewenangannya berdasarkan ketentuan UUD 1945.

Berdasarkan Pasal 24C ayat (1) UUD 1945 yang ditegaskan kembali dalam Pasal 10 ayat (1) huruf a sampai dengan d Undang-Undang Nomor 24 Tahun 2003 tentang Mahkamah Konstitusi (UU MK), kewenangan Mahkamah Konstitusi adalah menguji undang-undang terhadap UUD 1945; memutus sengketa kewenangan lembaga negara yang kewenangannya diberikan oleh UUD 1945; memutus pembubaran partai politik; dan memutus perselisihan tentang hasil pemilihan umum. Selain itu, berdasarkan Pasal 7 ayat (1) sampai dengan (5) dan Pasal 24C ayat (2) UUD 1945 yang ditegaskan lagi oleh Pasal 10 ayat (2) UU 24/2003, kewajiban Mahkamah Konstitusi adalah memberikan keputusan atas pendapat DPR bahwa Presiden dan/atau Wakil Presiden telah melakukan pelanggaran hukum, atau perbuatan tercela, atau tidak memenuhi syarat sebagai Presiden dan/atau Wakil Presiden sebagaimana dimaksud dalam UUD 1945.

Terkait dengan empat wewenang dan satu kewajiban yang dimilikinya, Jimly Asshidiqie beranggapan Mahkamah Konstitusi merupakan pengawal konstitusi (the guardian of the constitution). Hal itu juga membawa konsekuensi Mahkamah Konstitusi berfungsi sebagai penafsir konstitusi (the sole interpreter of the constitution). Konstitusi sebagai hukum tertinggi mengatur penyelenggaraan negara berdasarkan prinsip demokrasi dan salah satu fungsi konstitusi adalah melindungi hak asasi manusia yang dijamin dalam konstitusi sehingga menjadi hak konstitusional warga negara. Karena itu, Mahkamah Konstitusi juga berfungsi sebagai pengawal demokrasi (the guardian of the democracy), pelindung hak konstitusional warga negara (the protector of the citizen's constitutional rights) serta pelindung HAM (the protector of human rights). ${ }^{11}$

Laporan Tahunan Mahkamah Konstitusi Tahun 2018 menyebutkan bahwa total perkara pengujian undang-undang yang ditangani Mahkamah Konstitusi sejak 2003 hingga 2018

11 Jimly Asshiddiqie, Menuju Negara Hukum yang Demokratis, (Jakarta: Setjen dan Kepaniteraan MK RI, 2008), hlm. 39. 
sebanyak 1.236 perkara dan telah diputus sebanyak 1.199 perkara. ${ }^{12}$ Adapun rincian perkara yang diputus jika diklasifikasikan berdasarkan amar putusan, sebanyak 259 perkara dikabulkan, 420 perkara ditolak, 375 perkara tidak diterima, 21 perkara gugur, 115 perkara ditarik kembali, dan terhadap 9 perkara MK menyatakan tidak berwenang, sedangkan, sebanyak 37 perkara PUU masih dalam proses pemeriksaan pada akhir tahun 2018. ${ }^{13}$

Terkait dengan UU Pelayaran, sejauh ini terdokumentasi tiga perkara yang diajukan pengujiannya, yaitu dalam perkara 74/PUUVIII/2010, 65/PUU-XII/2014, dan 64/PUUXIII/2015. Selengkapnya termaktub dalam tabel di bawah ini:
Perkara yang paling penting untuk dikaji lebih lanjut adalah perkara Nomor 74/ PUU-VIII/2010. Hal ini dikarenakan perkara tersebut merupakan perkara yang ditolak. Artinya, Mahkamah Konstitusi juga membahas mengenai pokok permohonan dan telah masuk pada substansi konten UU Pelayaran.

\section{Putusan Mahkamah Konstitusi Nomor 74/PUU-VIII/2010 ${ }^{14}$}

Para Pemohon dalam permohonan ini adalah Bambang K. Rahwardi, H. Arlen Sitompul, dan H.M. Fuadi yang masing-masing adalah Ketua Umum, Sekretaris Umum, dan Kepala Bidang Organisasi Hukum dan Otoda Dewan Pimpinan Pusat Asosiasi Perusahaan Bongkar Muat Indonesia (DPP APBMI) yang

\section{Tabel 1}

Permohonan dan Putusan Mahkamah Konstitusi Terhadap UU Pelayaran

\begin{tabular}{|c|c|c|c|c|c|c|}
\hline No. & $\begin{array}{l}\text { Nomor } \\
\text { Perkara/ } \\
\text { Putusan }\end{array}$ & Pemohon & $\begin{array}{c}\text { Tanggal } \\
\text { Registrasi }\end{array}$ & $\begin{array}{l}\text { Tanggal } \\
\text { Putusan }\end{array}$ & $\begin{array}{c}\text { Amar } \\
\text { Putusan }\end{array}$ & Keterangan \\
\hline 1. & $\begin{array}{l}\text { 74/PUU- } \\
\text { VIII/2010 }\end{array}$ & $\begin{array}{l}\text { Bamban K. } \\
\text { Rahwardi, H. } \\
\text { Arlen Sitompul, } \\
\text { H. M. Fuadi. }\end{array}$ & 24-11-2010 & $21-12-2011$ & Ditolak & $\begin{array}{l}\text { Pokok perkara dibahas } \\
\text { oleh Mahkamah } \\
\text { Konstitusi }\end{array}$ \\
\hline 2. & $\begin{array}{l}\text { 65/PUU- } \\
\text { XII/2014 }\end{array}$ & $\begin{array}{l}\text { Musa, Yuyun } \\
\text { Wahyud, } \\
\text { Hasanudin Farid, } \\
\text { Al Ushudi, Arif } \\
\text { Ridwan }\end{array}$ & $10-07-2014$ & 22-01-2015 & $\begin{array}{l}\text { Tidak Dapat } \\
\text { Diterima }\end{array}$ & $\begin{array}{l}\text { Pokok perkara } \\
\text { tidak dibahas oleh } \\
\text { Mahkamah Konstitusi }\end{array}$ \\
\hline 3. & $\begin{array}{l}\text { 64/PUU- } \\
\text { XIII/2015 }\end{array}$ & $\begin{array}{l}\text { Capt. Ucok } \\
\text { Samuel } \\
\text { Bonaparte } \\
\text { Hutape, A.Md, } \\
\text { SH, SE.,M.Mar }\end{array}$ & 19-05-2015 & 21-06-2016 & $\begin{array}{l}\text { Tidak Dapat } \\
\text { Diterima }\end{array}$ & $\begin{array}{l}\text { Pokok perkara } \\
\text { tidak dibahas oleh } \\
\text { Mahkamah Konstitusi }\end{array}$ \\
\hline
\end{tabular}

Sumber: Sistem Informasi Mahkamah Konstitusi, diakses 1 April 2019.

12 Mahkamah Konstitusi, Mengawal Daulat Rakyat; Laporan Tahunan Mahkamah Konstitusi 2018, (Jakarta: Kepaniteraan dan Sekretariat Jenderal MKRI, 2019), hlm. 15.

13 Ibid.

14 Putusan ini dalam diunduh dalam laman www.mahkamahkonstitusi.go.id atau www.mkri.id, 
mewakili kepentingan organisasi dan para anggota dari APBMI yang beranggotakan 860 Perusahaan Bongkar Muat yang mana tujuan APBMI adalah mempersatukan perusahaan bongkar muat di Indonesia agar bisa saling berkomunikasi dan bekerjasama dalam meningkatkan peranan pengusaha bongkar muat serta memberikan arah yang pasti bagi dunia usaha bongkar muat, membantu usaha pemerintah dalam membina dan memajukan usaha bongkar muat di Indonesia guna menunjang Pembangunan Nasional serta membina dan menyalurkan cita, rasa, karsa, dan karya Perusahaan Bongkar Muat Indonesia demi tercapainya masyarakat yang adil dan makmur berdasarkan Pancasila dan UUD 1945. ${ }^{15}$

APBMI merupakan satu-satunya asosiasi wadah pengusaha jasa bongkar muat di pelabuhan Indonesia sesuai Surat Keputusan Menteri Perhubungan Nomor KP 6/AL 3014/ Phb-89 tentang Asosiasi Perusahaan Bongkar Muat Indonesia, tanggal 28 Oktober 1989. Hal ini ditegaskan dalam diktum Pertama Surat Keputusan tersebut yang menyatakan, "Mengakui Asosiasi Perusahaan Bongkar Muat Indonesia, selanjutnya dalam Keputusan ini disebut APBMI yang dibentuk oleh para pengusaha di bidang bongkar muat dalam Musyawarah Nasional I tanggal 28 Oktober 1988, merupakan satu-satunya organisasi pengusaha bongkar muat Indonesia". ${ }^{16}$

Para Pemohon mendalilkan ketentuan Pasal 90 ayat (3) huruf g UU Pelayaran memiliki potensi untuk disalahtafsirkan dalam hal implementasinya yaitu munculnya kemungkinan monopoli usaha di bidang bongkar muat barang oleh badan usaha pelabuhan dengan mengabaikan perusahaan yang khusus didirikan untuk kegiatan usaha bongkar muat barang. Pasal 90 ayat (3) huruf g UU Pelayaran yang menyatakan, "Penyediaan dan/atau pelayanan jasa kapal, penumpang, dan barang sebagaimana dimaksud pada ayat (2) terdiri atas: g. Penyediaan dan/atau pelayanan jasa bongkar muat barang." ${ }^{17}$

Dengan diberikannya hak melakukan kegiatan bongkar muat barang kepada Badan Usaha Pelabuhan, menurut para Pemohon, menyebabkan praktik monopoli yang selama ini berjalan cenderung berkelanjutan sehingga perusahaan bongkar muat yang eksistensi usaha jasa bongkar muat sudah dimiliki sejak tahun 1988 akan dimarginalisasi/ digusur sehingga lambat laun menimbulkan ketidakpastian usaha bagi banyak perusahaan bongkar muat, dengan hilangnya pangsa pasar yang akan dikuasai oleh PT. Pelabuhan Indonesia (Persero) [PT. Pelindo]. Dengan demikian, PT. Pelindo akan menguasai kegiatan di pelabuhan dari hulu sampai hilir. Menurut para Pemohon, untuk menghindari tafsir yang mengarah pada tumbuhnya atau terjadinya monopoli di bidang usaha bongkar muat barang, maka Pasal 90 ayat (3) huruf g UU Pelayaran yang menyatakan, “.... g. Penyediaan dan/atau pelayanan jasa bongkar muat barang" harus ditafsirkan sebagai pelayanan jasa yang terkait dengan penyediaan fasilitas jasa bongkar muat barang. ${ }^{18}$

\footnotetext{
15 https://mkri.id/public/content/persidangan/putusan/putusan_sidang_74\%20PUU\%202010_telah\%20 BACA.pdf, diakses 1 April 2019.

16 Ibid.

17 Ibid.

18 Ibid.
} 
Terhadap permohonan tersebut, Pemerintah beranggapan bahwa tidak benar Pasal 90 ayat (3) huruf g UU Pelayaran bersifat diskriminatif terhadap pelaku ekonomi dan melahirkan praktek monopoli di pelabuhan yang dianggap bertentangan dengan UUD 1945 karena UU pelayaran justru memberikan hak yang sama kepada badan usaha pelabuhan dan perusahaan bongkar muat untuk melakukan kegiatan bongkar muat barang di pelabuhan. Lebih lanjut menurut Pemerintah, ketentuan mengenai penyediaan fasilitas untuk kegiatan bongkar muat telah diatur dalam Pasal 90 ayat (3) huruf d UU Pelayaran yang menyatakan, "penyediaan dan/atau pelayanan jasa dermaga untuk pelaksanaan kegiatan bongkar muat barang dan peti kemas" dan Pasal 90 ayat (3) huruf e UU Pelayaran yang menyatakan, "Penyediaan dan/atau pelayanan jasa gudang dan tempat penimbunan barang, alat bongkar muat, serta peralatan pelabuhan."19

DPR dalam keterangannya menyatakan bahwa Pasal 90 UU Pelayaran telah mengatur bahwa kegiatan pengusahaan di pelabuhan terdiri atas penyediaan dan/atau pelayanan jasa kepelabuhanan dan jasa terkait dengan kepelabuhanan. Pertama, kegiatan pelayanan jasa kepelabuhanan meliputi penyediaan dan atau pelayanan jasa kapal, penumpang dan barang, yang terdiri atas: (a) penyediaan dan/ atau pelayanan jasa dermaga untuk bertambat; (b) penyediaan dan/atau pelayanan pengisian bahan bakar dan pelayanan air bersih; (c) penyediaan dan/atau pelayanan fasilitas naik turun penumpang dan/atau kendaraan; (d) penyediaan dan/atau pelayanan jasa dermaga untuk pelaksanaan kegiatan bongkar muat barang dan peti kemas; (e) penyediaan dan/atau pelayanan jasa gudang dan tempat penimbunan barang, alat bongkar muat serta peralatan pelabuhan; (f) penyediaan dan/ atau pelayanan jasa terminal peti kemas, curah cair, dan curah kering; (g) penyediaan dan/atau pelayanan jasa bongkar muat barang; (h) penyediaan dan/atau pelayanan pusat distribusi dan konsolidasi barang dan/ atau (i) penyediaan dan/atau pelayanan jasa penundaan kapal. Kegiatan penyediaan dan/ atau pelayanan jasa kepelabuhanan pada pelabuhan yang diusahakan secara komersial dilaksanakan oleh Badan Usaha Pelabuhan sesuai dengan izin usaha yang dimilikinya, dan dilaksanakan oleh Unit Penyelenggara Pelabuhan bagi pelabuhan yang belum diusahakan secara komersial. Kedua, Kegiatan jasa terkait dengan kepelabuhanan meliputi kegiatan yang menunjang kelancaran operasional dan memberikan nilai tambah bagi pelabuhan, antara lain perkantoran, fasilitas pariwisata dan perhotelan, instalasi air bersih, listrik dan telekomunikasi, jaringan air limbah dan sampah, pelayanan bungker dan tempat tunggu kendaraan bermotor. Kegiatan jasa terkait dilakukan oleh orang perseorangan warga negara Indonesia dan/ atau badan usaha. ${ }^{20}$

Lebih lanjut menurut DPR, penyediaan dan/ atau pelayanan jasa bongkar muat barang di pelabuhan berlaku untuk setiap Badan Usaha yang memenuhi ketentuan UU Pelayaran, dan penyediaan dan/atau pelayanan jasa bongkar muat barang di Pelabuhan dilakukan oleh Badan Usaha yaitu Badan Usaha Pelabuhan,

19 Ibid.

20 Ibid. 
Perusahaan Bongkar Muat, dan Perusahaan Angkutan Laut Nasional, yang masing-masing Badan Usaha tersebut memiliki fungsi dan kewenangan yang berbeda sesuai dengan ketentuan peraturan perundang-undangan, dengan demikian tidak ada yang diskriminatif terhadap Badan Usaha sebagai pelaku ekonomi. ${ }^{21}$

Mahkamah Konstitusi dalam pendapatnya menyatakan bahwa Pasal 90 ayat (3) huruf g UU Pelayaran merupakan ketentuan yang menyebutkan salah satu jenis kegiatan pengusahaan di pelabuhan tanpa sama sekali menyebutkan subjek hukum yang boleh atau tidak boleh melakukan kegiatan tersebut. Sebagai jenis kegiatan, menurut Mahkamah, penyebutan jenis kegiatan tersebut tidak memiliki masalah konstitusionalitas. Tidak ada subjek hukum yang dirugikan maupun diuntungkan dalam penyebutan jenis kegiatan ini. $^{22}$

Terdapat alasan oleh para Pemohon bahwa Pasal 90 ayat (3) huruf g UU Pelayaran bertentangan dengan UUD 1945 adalah adanya Surat Edaran Menteri Perhubungan Nomor S.E. 6 Tahun 2002 yang memberikan wewenang kepada PT. Pelindo untuk melakukan kegiatan sebagaimana disebutkan dalam Pasal 90 ayat (3) huruf g UU Pelayaran, sehingga para Pemohon dirugikan dengan adanya PT. Pelindo sebagai operator yang dianggap mengambil porsi/ bagian dari pekerjaan para Pemohon. Artinya, para Pemohon tidak akan dirugikan jika PT. Pelindo hanya diberi hak untuk menyediakan pelayanan fasilitas jasa bongkar muat barang saja, bukan jasa bongkar muat itu sendiri. Menurut Mahkamah Konstitusi, berlakunya
Surat Edaran Menteri Perhubungan Nomor S.E. 6 Tahun 2002 dan pengaturan terkait dengan hal tersebut merupakan permasalahan penerapan hukum belaka.

Para Pemohon juga mendalilkan, ketentuan Pasal 90 ayat (3) huruf g UU Pelayaran bersifat diskriminatif terhadap pelaku ekonomi, sehingga bertentangan dengan UUD 1945. Untuk mempertimbangkan hal tersebut, Mahkamah Konstitusi mengutip Putusan Nomor 028-029/PUU-IV/2006 bertanggal 12 April 2007 yang menyatakan,

“... Pasal 1 Ayat (3) Undang-Undang Nomor 39 Tahun 1999 tentang Hak Asasi Manusia berbunyi, 'Diskriminasi adalah setiap pembatasan, pelecehan, atau pengucilan yang langsung atau tak langsung didasarkan pada pembedaan manusia atas dasar agama, suku, ras, etnik, kelompok, golongan, status sosial, status ekonomi, jenis kelamin, bahasa, keyakinan politik, yang berakibat pengurangan, penyimpangan, atau penghapusan, pengakuan, pelaksanaan atau penggunaan hak asasi manusia dan kebebasan dasar dalam kehidupan baik individual maupun kolektif dalam bidang politik, ekonomi, hukum, sosial, budaya, dan aspek kehidupan lainnya'. Ketentuan mengenai larangan diskriminasi di atas juga diatur dalam International Covenant on Civil and Political Rights (ICCPR) yang telah diratifikasi oleh Indonesia dengan UndangUndang Nomor 12 Tahun 2005 (Lembaran Negara Republik Indonesia Tahun 2005 Nomor 119, Tambahan Lembaran Negara Republik Indonesia Nomor 4558). Article 2 ICCPR berbunyi, 'Each State Party to the present Covenant undertakes to respect and ensure to all individuals within its territory and subject to its jurisdiction the rights recognized in the present Covenant, without distinction of any kind, such as race, color, sex, language, religion, political or other opinion, national or social origin, property, birth or other status'". Dengan

21 Ibid.

22 Ibid. 
demikian, diskriminasi harus diartikan sebagai setiap pembatasan, pelecehan, atau pengucilan yang didasarkan pada pembedaan manusia atas dasar agama (religion), ras (race), warna kulit (color), jenis kelamin (sex), bahasa (language), dan pandangan politik (political opinion)." ${ }^{23}$

Berdasarkan ukuran diskriminasi sebagaimana diuraikan di atas, maka dalil mengenai penyebutan jenis kegiatan tertentu sebagaimana disebutkan dalam Pasal 90 ayat (3) huruf g UU Pelayaran, menurut Mahkamah Konstitusi, bukanlah diskriminasi sebagaimana dimaksud dalam konstitusi.

Terkait dengan frasa "penyediaan dan/ atau pelayanan jasa bongkar muat barang" pun berlaku bagi siapa saja yang memenuhi persyaratan untuk melakukan kegiatan pengusahaan pelabuhan sesuai dengan ketentuan yang berlaku. Hal ini diperkuat oleh keterangan yang disampaikan oleh Dewan Perwakilan Rakyat bahwa penyediaan dan/ atau pelayanan jasa bongkar muat barang di pelabuhan berlaku untuk setiap Badan Usaha yang memenuhi ketentuan UU Pelayaran, dan penyediaan dan/atau pelayanan jasa bongkar muat barang di pelabuhan dilakukan oleh Badan Usaha, yaitu Badan Usaha Pelabuhan, Perusahaan Bongkar Muat, dan Perusahaan Angkutan Laut Nasional, yang masing-masing Badan Usaha tersebut memiliki fungsi dan kewenangan yang berbeda sesuai dengan ketentuan peraturan perundang-undangan, dengan demikian, tidak ada hal yang diskriminatif terhadap Badan Usaha sebagai pelaku ekonomi. ${ }^{24}$

Mahkamah Konstitusi juga menyatakan tidak berwenang menambah kata "fasilitas" pada frasa "penyediaan dan/atau pelayanan jasa bongkar muat barang" menjadi frasa "penyediaan dan/atau pelayanan fasilitas jasa bongkar muat barang". Sebab dengan melakukan itu berarti Mahkamah memasuki ranah legislatif dengan ikut mengatur isi Undang-Undang yang bersifat opened legal policy.

Terkait dengan dalil para Pemohon bahwa jika PT. Pelindo tetap akan diberikan hak untuk melakukan kegiatan usaha bongkar muat barang berdasarkan Pasal 90 ayat (3) huruf g UU Pelayaran, maka praktik monopoli akan berjalan lebih kuat lagi dan akan menimbulkan keresahan dengan munculnya iklim usaha yang tidak kondusif dalam kegiatan usaha jasa bongkar muat barang di pelabuhan. Menurut Mahkamah Konstitusi, Pasal 33 UUD 1945 tidak menolak ide kompetisi di antara para pelaku usaha, sepanjang kompetisi tidak meniadakan penguasaan oleh negara yang mencakup kekuasaan untuk mengatur (regelendaad), mengurus (bestuursdaad), mengelola (beheersdaad), dan mengawasi (toezichthoudensdaad) cabang-cabang produksi yang penting bagi negara dan/atau yang menguasai hajat hidup orang banyak untuk tujuan sebesar-besarnya kemakmuran rakyat (vide Putusan Nomor 001-021-022/ PUU-I/2003, bertanggal 15 Desember 2004). ${ }^{25}$

Bahwa kondisi pelabuhan di Indonesia satu sama lain tidak sama, sedangkan para Pemohon hanya mempersoalkan kewenangan PT. Pelindo sebagai operator bongkar muat di pelabuhan yang sudah maju dan berkembang, padahal banyak pelabuhan, khususnya di daerah Indonesia bagian timur,

\footnotetext{
Ibid.

24 Ibid.

25 Ibid.
} 
yang tidak ada pengusaha yang membuka usaha bongkar muat, sehingga PT. Pelindo harus menyediakan jasa bongkar muat demi melayani kepentingan masyarakat karena apabila PT. Pelindo tidak melakukannya maka akan merugikan masyarakat. Oleh karena itu ketentuan Pasal 90 ayat (3) huruf g UU Pelayaran yang kemudian dituangkan dalam Surat Edaran Menteri Perhubungan Nomor S.E. 6 Tahun 2002 bahwa PT. Pelindo dapat melakukan jasa bongkar muat, dapat dibenarkan. ${ }^{26}$

Bahwa terhadap dalil para Pemohon yang menyatakan, PT. Pelindo merupakan regulator sekaligus operator, Mahkamah berpendapat, fungsi tersebut tidak bertentangan dengan UUD 1945 sebab fungsi PT. Pelindo dalam mengimplementasikan tata kelola memang dapat mencakup fungsi regulator sekaligus operator sepanjang fungsi regulator tersebut merupakan pelaksanaan lebih lanjut dari UU Pelayaran. Selain itu, oleh karena fungsi regulator dan operator itu merupakan penafsiran para Pemohon terhadap Surat Edaran Menteri Perhubungan Nomor S.E. 6 Tahun 2002 maka seandainya pun penafsiran para Pemohon tersebut benar, quod non, hal tersebut menjadi kewenangan pengadilan lain untuk mengujinya. Dengan demikian, menurut Mahkamah Konstitusi dalil para Pemohon, tidak beralasan menurut hukum. ${ }^{27}$

\section{Analisis Putusan}

Putusan Mahkamah Konstitusi Nomor 74/PUU-VIII/2010 dapat dikatakan sebagai sebuah putusan yang penting di bidang maritim, walaupun belum dapat dikatakan sebagai landmark decision. Jika dilihat konten putusan tersebut terdapat beberapa hal yang bisa dijadikan rujukan dalam memaknai UU Pelayaran atau isu maritim secara umum.

Pertama, Pasal 90 ayat (3) huruf g UU Pelayaran merupakan ketentuan yang menyebutkan salah satu jenis kegiatan pengusahaan di pelabuhan tanpa sama sekali menyebutkan subjek hukum yang boleh atau tidak boleh melakukan kegiatan tersebut. Penyebutan jenis kegiatan demikian tidaklah memiliki masalah konstitusionalitas karena tidak ada subjek hukum yang dirugikan maupun diuntungkan dalam penyebutan jenis kegiatan ini.

Menurut penulis, hal ini adalah terkait dengan konsep kerugian konstitusional yang dikenal dalam proses pengujian undangundang (judicial review). Berdasarkan Pasal 51 ayat (1) UU MK beserta Penjelasannya, yang dapat mengajukan permohonan pengujian undang-undang terhadap UUD 1945 adalah mereka yang menganggap hak dan/atau kewenangan konstitusionalnya yang diberikan oleh UUD 1945 dirugikan oleh berlakunya suatu Undang-Undang, yaitu: a. perorangan warga negara Indonesia (termasuk kelompok orang yang mempunyai kepentingan sama); b. kesatuan masyarakat hukum adat sepanjang masih hidup dan sesuai dengan perkembangan masyarakat dan prinsip Negara Kesatuan Republik Indonesia yang diatur dalam undang-undang; c. badan hukum publik atau privat; atau d. lembaga negara; Dengan demikian, Pemohon dalam pengujian Undang-Undang terhadap UUD 1945 harus menjelaskan terlebih 
dahulu: a. kedudukannya sebagai Pemohon sebagaimana dimaksud dalam Pasal 51 ayat (1) UU MK; b. ada tidaknya kerugian hak dan/atau kewenangan konstitusional yang diberikan oleh UUD 1945 yang diakibatkan oleh berlakunya Undang-Undang yang dimohonkan pengujian dalam kedudukan sebagaimana dimaksud pada huruf a.

Mahkamah sejak Putusan Nomor 006/ PUU-III/2005 tanggal 31 Mei 2005 dan Putusan Nomor 11/PUU-V/2007 tanggal 20 September 2007 serta putusan-putusan selanjutnya, juga telah berpendirian bahwa kerugian hak dan/ atau kewenangan konstitusional sebagaimana dimaksud dalam Pasal 51 ayat (1) UU MK harus memenuhi 5 (lima) syarat, yaitu:

a. adanya hak dan/atau kewenangan konstitusional para Pemohon yang diberikan oleh UUD 1945;

b. hak dan/atau kewenangan konstitusional tersebut oleh para Pemohon dianggap dirugikan oleh berlakunya undang-undang yang dimohonkan pengujian;

c. kerugian konstitusional tersebut harus bersifat spesifik (khusus) dan aktual atau setidak-tidaknya potensial yang menurut penalaran yang wajar dapat dipastikan akan terjadi;

d. adanya hubungan sebab-akibat antara kerugian dimaksud dan berlakunya undang-undang yang dimohonkan pengujian;

e. adanya kemungkinan bahwa dengan dikabulkannya permohonan, maka kerugian konstitusional seperti yang didalilkan tidak akan atau tidak lagi terjadi;
Dengan mendasarkan dengan hal-hal tersebut, Mahkamah Konstitusi dalam Putusan Nomor 74/PUU-VIII/2010 menegaskan bahwa kerugian konstitusional memang mengacu pada subjek tertentu. Norma yang terkait dengan objek jenis kegiatan tertentu menjadi tidak memiliki masalah konstitusionalitas jika tidak ada subjek hukum yang dirugikan maupun diuntungkan dalam penyebutan norma yang diuji oleh Mahkamah Konstitusi. Pendapat demikian dapat menjadi rujukan dalam menilai konstitusionalitas norma apapun yang diajukan dalam format pengujian undang-undang secara umum.

Kedua, penegasan pemaknaan atas diskriminasi dalam konteks hukum. Diskriminasi dalam Kamus Besar Bahasa Indonesia versi daring adalah pembedaan perlakuan terhadap sesama warga negara (berdasarkan warna kulit, golongan, suku, ekonomi, agama, dan sebagainya). ${ }^{28}$ Definisi tersebut tidaklah jauh dari definisi hukum dari berbagai instrumen hukum.

Pasal 7 Deklarasi Umum Hak Asasi Manusia (DUHAM) menyatakan bahwa semua orang sama di depan hukum dan berhak atas perlindungan hukum yang sama tanpa diskriminasi. Semua berhak atas perlindungan yang sama terhadap setiap bentuk diskriminasi yang bertentangan dengan Deklarasi ini, dan terhadap segala hasutan yang mengarah pada diskriminasi semacam ini. ${ }^{29}$ Pasal 8 Piagam Hak Asasi Manusia yang merupakan bagian dalam Ketetapan Majelis Permusyawaratan Rakyat Republik Indonesia Nomor XVII /MPR/1998 tentang Hak Asasi Manusia menyatakan,

28 [https://kbbi.kemdikbud.go.id/entri/diskriminasi], diakses 1 April 2019.

29 [https://www.komnasham.go.id/files/1475231326-deklarasi-universal-hak-asasi--\$R48R63.pdf], diakses 1 April 2019. 
"Setiap orang berhak mendapat kepastian hukum dan perlakuan yang sama di hadapan hukum." ${ }^{30}$

Selain itu, terdapat Undang-Undang Nomor 39 Tahun 1999 tentang Hak Asasi Manusia dimana pada Pasal 1 angka 3 mendefinisikan diskriminasi sebagai setiap pembatasan, pelecehan, atau pengucilan yang langsung ataupun tak langsung didasarkan pada pembedaan manusia atas dasar agama, suku, ras, etnik, kelompok, golongan, status sosial, status ekonomi, jenis kelamin, bahasa, keyakinan politik, yang berakibat pengurangan, penyimpangan, atau penghapusan pengakuan, pelaksanaan, atau penggunaan hak asasi manusia dan kebebasan dasar dalam kehidupan baik individual maupun kolektif dalam bidang politik, ekonomi, hukum, sosial, budaya dan aspek kehidupan lainnya. ${ }^{31}$

Definisi inilah yang kemudian digunakan oleh Mahkamah Konstitusi dalam menafsirkan tindakan yang bersifat diskriminatif itu apa. Secara lugas, Mahkamah Konstitusi dalam Putusan Nomor 028-029/PUU-IV/2006 bertanggal 12 April 2007 menetapkan diskriminasi sebagai setiap pembatasan, pelecehan, atau pengucilan yang didasarkan pada pembedaan manusia atas dasar agama (religion), ras (race), warna kulit (color), jenis kelamin (sex), bahasa (language), dan pandangan politik (political opinion). Definisi ini kemudian dipertegas lagi dengan Putusan Nomor 74/PUU-VIII/2010.

Terkait dengan UU Pelayaran yang diuji, Mahkamah Konstitusi juga tegas menyatakan, frasa "penyediaan dan/atau pelayanan jasa bongkar muat barang" pun berlaku bagi siapa saja yang memenuhi persyaratan untuk melakukan kegiatan pengusahaan pelabuhan sesuai dengan ketentuan yang berlaku. Penyediaan dan/atau pelayanan jasa bongkar muat barang di pelabuhan berlaku untuk setiap Badan Usaha yang memenuhi ketentuan UU Pelayaran, dan penyediaan dan/ atau pelayanan jasa bongkar muat barang di pelabuhan dilakukan oleh Badan Usaha, yaitu Badan Usaha Pelabuhan, Perusahaan Bongkar Muat, dan Perusahaan Angkutan Laut Nasional. Menurut Mahkamah Konstitusi, masing-masing Badan Usaha tersebut memiliki fungsi dan kewenangan yang berbeda sesuai dengan ketentuan peraturan perundangundangan, dengan demikian, tidak ada hal yang diskriminatif terhadap Badan Usaha sebagai pelaku ekonomi di bidang maritim tersebut.

Hal ini dapat menjadi rujukan bagi pengaturan norma khususnya dalam pembangunan hukum di bidang maritim agar tidak menciptakan peraturan yang bersifat diskriminatif. Dengan definisi diskriminasi oleh Mahkamah Konstitusi yang telah menjadi rujukan penting dan penegasan dari Putusan Nomor 74/PUU-VIII/2010 inilah pembentukan peraturan perundang-undangan di bidang maritim dapat lebih jelas dan yakin dalam merancang norma.

Ketiga, Mahkamah Konstitusi secara jelas membatasi dirinya untuk melakukan judicial activism terhadap norma yang bersifat opened legal policy di bidang pelayaran dan maritim. Mahkamah Konstitusi malah melakukan judicial restraint dan berhati-hati untuk tidak

\footnotetext{
30 [http://hukum.unsrat.ac.id/uu/mpr_17_98.htm], diakses 1 April 2019.
}

31 [http://hukum.unsrat.ac.id/uu/uu_39_99.htm], diakses 1 April 2019. 
masuk ke ranah pembentukan hukum dalam UU Pelayaran.

Menurut Pan Mohamad Faiz, teori mengenai pembatasan yudisial (judicial restraint) pertama kali diperkenalkan oleh James B. Thayer dalam tulisannya "The Origin and Scope of the American Doctrine of Constitutional Law". Teori ini menggunakan pendekatan dengan menempatkan pengadilan agar membatasi atau menahan diri dalam membuat kebijakan yang menjadi ranah kewenangan legislator, eksekutif, dan pembentuk peraturan perundang-undangan lainnya. ${ }^{32}$

Lebih lanjut Faiz menguraikan pendapat Richard A. Posner yang membagi pendekatan ini ke dalam tiga kategori. Pertama, legalism atau formalism sebagai suatu pendekatan bahwa hakim hanya menjalankan hukum dan tidak untuk membuatnya. Kedua, modesty, institutional competence, atau process jurisprudence yang menempatkan hakim untuk menghormati dan tidak memasuki ranah kewenangan legislatif atau eksekutif dalam membuat keputusan atau kebijakan. Ketiga, constitutional restraint yang menempatkan hakim untuk sangat enggan menyatakan inkonstitusional dari suatu keputusan atau tindakan eksekutif maupun legislatif. ${ }^{33}$

"Pendekatan terhadap teori ini menuntut agar pengadilan dan para hakimnya memahami batasan-batasan atas kewenangan dan kemampuannya, sehingga mampu menahan diri untuk tidak mengadili atau membuat kebijakan yang bukan menjadi ranah kewenangannya. Dalam proses ajudikasi konstitusional, judicial restraint lebih pada tingkatan atau derajat yang perlu dipahami oleh para hakim mengenai kapan dan sejauh mana mereka harus mengadili keputusan atau kebijakan dari lembaga legislatif dan eksekutif dalam keadaan yang tepat." 34

Secara terperinci, Aileen Kavanagh sebagaimana ditulis Pan Mohamad Faiz, memberikan empat alasan dan kondisi untuk menggunakan pendekatan judicial restraint ini. Pertama, keterbatasan keahlian peradilan untuk memutus sesuatu yang sangat kompleks dan tidak dapat memprediksi konsekuensikonsekuensi lain yang akan muncul dari putusannya. Kedua, sifat inkremental dari putusan pengadilan dengan menyadari bahwa reformasi atau pertimbangan parsial justru bisa membawa resiko yang kontraproduktif sehingga akan gagal mencapai harapan atau maksud yang ingin dituju. Ketiga, adanya legitimasi demokratis dan akuntablitas lembaga pengadilan yang lebih rendah dibandingkan dengan legislator dan eksekutif dalam membuat suatu putusan atau kebijakan. Keempat, menjaga reputasi dan memberikan kepercayaan publik terhadap pengadilan sebagai pemutus yang adil sehingga keputusannya dihormati, baik oleh parlemen, eksekutif, dan masyarakat luas. ${ }^{35}$

Dengan demikian dapat kita pahami mengapa Mahkamah Konstitusi dalam Putusan 74/PUU-VIII/2010 menolak menambah kata "fasilitas" sebagaimana yang dimintakan oleh para Pemohon. Selain itu, jika diperhatikan UUD 1945 itu sendiri tidak ditemukan adanya pengaturan terkait maritim atau kelautan atau 
pelayaran. Kata "laut" sebagai padanan kata "maritim" dalam UUD 1945 hanya termaktub dalam Pasal 10 UUD 1945 yang menyatakan, "Presiden memegang kekuasaan yang tertinggi atas Angkatan Darat, Angkatan Laut dan Angkatan Udara." Pasal 30 ayat (3) UUD 1945 hanya menyebutkan, "Tentara Nasional Indonesia terdiri atas Angkatan Darat, Angkatan laut dan Angkatan Udara sebagai alat negara bertugas mempertahankan, melindungi, dan memelihara keutuhan dan kedaulatan negara."

Yang paling mendekati pengaturan tentang maritim dalam konteks wilayah adalah Pasal 33 ayat (3) UUD 1945 yang menyatakan, "bumi dan air dan kekayaan alam yang terkandung di dalamnya dikuasai oleh negara dan dipergunakan untuk sebesarbesar kemakmuran rakyat," Norma UUD 1945 itu juga hanya berbicara penguasaan air oleh negara. Artinya, UUD 1945 sebagai konstitusi negara tidaklah mengatur secara rinci mengenai pelayaran atau maritim. Pengaturan lebih lanjut merupakan kewenangan legislator atau DPR bersama presiden. Hal inilah yang disebut sebagai kebijakan hukum terbuka (open legal policy).

Mardian Wibowo dalam tulisannya "Menakar Konstitusionalitas Sebuah Kebijakan Hukum Terbuka dalam Pengujian UndangUndang" menyatakan, di bidang ilmu hukum, konsep open legal policy adalah hal baru dan relatif tidak dikenal sebelumnya. Selama ini istilah policy (kebijakan) lebih dikenal luas dalam bidang studi kebijakan publik, antara lain dalam istilah communitarian policy (kebijakan masyarakat), public policy (kebijakan publik), dan social policy (kebijakan sosial). ${ }^{36}$

Di bidang ilmu kebijakan publik, menurut Mardian Wibowo, istilah kebijakan (policy) sudah mengandung makna bebas atau terbuka (open), karena pada dasarnya makna kebijakan selalu merujuk pada keleluasaan pejabat/pihak berwenang untuk melakukan hal-hal tertentu yang pelaksanaannya tidak atau belum diatur secara jelas oleh peraturan perundang-undangan. Hal demikian berbeda dengan pengertian terbuka (open) di bidang pembentukan hukum. ${ }^{37}$ Kata "terbuka" dalam istilah "kebijakan hukum terbuka" dapat diartikan sebagai suatu kebebasan bagi pembentuk undang-undang untuk mengambil kebijakan hukum. ${ }^{38}$

Walau demikian, menurut Mardian Wibowo, dalam perkembangannya, konsep open legal policy yang ditafsirkan Mahkamah Konstitusi sebagai kebebasan bagi pembentuk UU untuk sebebas-bebasnya menyusun kebijakan hukum, ternyata kemudian dibatasi sendiri oleh Mahkamah Konstitusi dengan merujuk pada Pasal 28J ayat (2) UUD 1945. ${ }^{39}$

"Dengan menafsirkan Pasal 28J ayat (2) secara ekstensif dan lebih progresif ditemukan pembatasan bagi konsep open legal policy. Dengan demikian suatu Open Legal Policy akan konstitusional jika telah menerapkan metode yang menjamin keadilan, salah satunya melalui penerapan "strategi maximin". Pembatasan demikian, karena dituangkan dalam Putusan MK tentu berakibat mengikat bagi semua pihak (erga omnes), terutama bagi pembentuk

Ibid., hlm. 211.

37 Mardian Wibowo, "Menakar Konstitusionalitas sebuah Kebijakan Hukum Terbuka dalam Pengujian UndangUndang", Jurnal Konstitusi, Volume 12, Nomor 2, Juni 2015, hlm. 210.

38 Ibid.

$39 \quad$ Ibid., hlm. 215. 
UU yang menjadi "adresat" Putusan MK. Namun demikian "strategi maximin" tentu bukan harga mati. Selalu mungkin ditemukan metode yang lebih tepat dalam upaya mendekati keadilan. Ketika metode itu ditemukan, baik MK maupun pembentuk undang-undang, dalam konteks pembentukan dan/atau pengujian undangundang, harus bersedia untuk secara rasional memperbaiki tindakan, pendapat, dan/atau penilaiannya." ${ }^{40}$

Terlepas dari hal tersebut, menurut penulis, Mahkamah Konstitusi telah menafsirkan adanya kebijakan hukum terbuka (open legal policy) pada pengaturan dalam UU Pelayaran sebagaimana yang telah ditentukan oleh 74/ PUU-VIII/2010 walaupun hanya mengacu dalam norma yang dimohonkan untuk diuji saja. Hal ini membuka kesempatan untuk membuat aturan lebih lanjut dalam peraturan perundang-undangan di bawah undangundang yang mengatur tentang maritim dengan mempertimbangkan Pasal 28J ayat (2) UUD 1945.

Keempat, tudingan monopoli dalam UU Pelayaran dan nilai-nilai ekonomis maritim lainnya. Hal ini terkait dengan keberadaan PT. Pelindo yang diberikan hak untuk melakukan kegiatan usaha bongkar muat barang berdasarkan Pasal 90 ayat (3) huruf g UU Pelayaran. Untuk menjawab hal tersebut, Mahkamah Konstitusi menafsirkan Pasal 33 UUD 1945 yang tidak menolak ide kompetisi di antara para pelaku usaha, sepanjang kompetisi tidak meniadakan penguasaan oleh negara yang mencakup kekuasaan untuk mengatur (regelendaad), mengurus (bestuursdaad), mengelola (beheersdaad), dan mengawasi (toezichthoudensdaad) cabang-cabang produksi yang penting bagi negara dan/atau yang menguasai hajat hidup orang banyak untuk tujuan sebesar-besarnya kemakmuran rakyat. Pandangan ini sebenarnya mengutip Putusan Nomor 001-021-022/PUU-1/2003, bertanggal 15 Desember 2004.

Dalam Putusan Nomor 001-021-022/ PUU-I/2003 tersebut, Mahkamah Konstitusi menyatakan bahwa untuk melakukan pengujian undang-undang terhadap Pasal 33 ayat (2) UUD 1945, Mahkamah Konstitusi memberi pengertian atau makna "dikuasai oleh negara" sebagaimana dicantumkan dalam Pasal 33 ayat (2) UUD 1945. Pasal 33 ayat (2) UUD 1945 mempunyai daya berlaku normatif sebagai berikut: ${ }^{41}$

1. Konstitusi memberikan kewenangan kepada negara untuk menguasai cabangcabang produksi yang penting bagi negara dan yang menguasai hajat hidup orang banyak;

2. Kewenangan tersebut ditujukan kepada mereka baik yang akan maupun yang telah mengusahakan produksi yang penting bagi negara dan yang menguasai hajat hidup orang banyak. Pada cabang produksi yang jenis produksinya belum ada atau baru akan diusahakan, yang jenis produksi tersebut penting bagi negara dan menguasai hajat

40 Ibid.

41 Pasal 33 pasca Perubahan UUD 1945 selengkapnya berbunyi: “(1) Perekonomian disusun sebagai usaha bersama berdasar atas asas kekeluargaan. (2) Cabang-cabang produksi yang penting bagi negara dan yang menguasai hajat hidup orang banyak dikuasai oleh negara. (3) Bumi dan air dan kekayaan alam yang terkandung di dalamnya dikuasai oleh negara dan dipergunakan untuk sebesar-besar kemakmuran rakyat. (4) Perekonomian nasional diselenggarakan berdasar atas demokrasi ekonomi dengan prinsip kebersamaan, efisiensi berkeadilan, berkelanjutan, berwawasan lingkungan, kemandirian, serta dengan menjaga keseimbangan kemajuan dan kesatuan ekonomi nasional. (5) Ketentuan lebih lanjut mengenai pelaksanaan pasal ini diatur dalam undang-undang." 
hidup orang banyak negara mempunyai hak diutamakan/didahulukan yaitu negara mengusahakan sendiri dan menguasai cabang produksi tersebut serta pada saat yang bersamaan melarang perorangan atau swasta untuk mengusahakan cabang produksi tersebut;

3. Pada cabang produksi yang telah diusahakan oleh perorangan atau swasta dan ternyata produksinya penting bagi negara dan menguasai hajat hidup orang banyak, atas kewenangan yang diberikan oleh Pasal 33 ayat (2) UUD 1945, negara dapat mengambil alih cabang produksi tersebut dengan cara yang sesuai dengan aturan hukum yang adil; ${ }^{42}$

Menurut Mahkamah Konstitusi, kewenangan negara yang diberikan oleh UUD 1945 dapat digunakan sewaktu-waktu apabila unsur-unsur persyaratan penting bagi negara dan/atau menguasai hajat hidup orang banyak sebagaimana tercantum dalam Pasal 33 ayat (2) terpenuhi. Selain itu, ketentuan UUD 1945 yang memberikan kewenangan kepada negara untuk menguasai cabangcabang produksi yang penting bagi negara dan menguasai hajat hidup orang banyak tidaklah dimaksudkan demi kekuasaan semata dari negara, tetapi mempunyai maksud agar negara dapat memenuhi kewajibannya sebagaimana disebutkan dalam Pembukaan UUD 1945, “.... melindungi segenap bangsa Indonesia dan seluruh tumpah darah Indonesia dan untuk memajukan kesejahteraan umum ..." dan juga "mewujudkan suatu keadilan sosial bagi seluruh rakyat Indonesia". ${ }^{43}$

"Misi yang terkandung dalam penguasaan negara tersebut dimaksudkan bahwa negara harus menjadikan penguasaan terhadap cabang produksi yang dikuasainya itu untuk memenuhi tiga hal yang menjadi kepentingan masyarakat, yaitu: (1) ketersediaan yang cukup, (2) distribusi yang merata, dan (3) terjangkaunya harga bagi orang banyak. Hubungan antara penguasaan negara atas cabang produksi yang penting bagi negara dan hajat hidup orang banyak, serta misi yang terkandung dalam penguasaan negara merupakan keutuhan paradigma yang dianut oleh UUD 1945, bahkan dapat dikatakan sebagai cita hukum (rechtsidee) dari UUD 1945. Dengan demikian jelas bahwa UUD 1945 telah menentukan pilihannya. Pertanyaannya, bukankah ketiga hal tersebut di atas dapat dipenuhi oleh sistem ekonomi pasar, dan oleh karenanya mengapa tidak diserahkan saja kepada mekanisme pasar, tentu haruslah dijawab secara normatif bahwa UUD 1945 tidak memilih sistem tersebut sebagaimana tercermin dalam Pasal 33 ayat (4). Dasar pilihan tersebut tidak berarti tanpa alasan sama sekali." ${ }^{44}$

Asumsi bahwa mekanisme pasar dapat secara otomatis memenuhi ketiga hal tersebut di atas adalah penyederhanaan logika yang jauh dari kenyataan, yaitu adanya mekanisme (sistem) pasar yang sempurna. Untuk itu, Mahkamah Konstitusi mengutip Joseph E. Stiglitz: "... presumption that markets, by themselves, lead to efficient outcomes, failed to allow for desirable government interventions in the market and make everyone better off." (Globalization and Its Discontents, Joseph E. Stiglitz, hal. XII). ${ }^{45}$

\footnotetext{
42 Putusan Mahkamah Konstitusi Nomor 001-021-022/PUU-I/2003 pada [https://mkri.id/public/content/ persidangan/putusan/Putusan001PUUI2003.pdf], diakses 1 April 2019.

43 Ibid.

44 Ibid.

45 Ibid.
} 
Berdasarkan penafsiran historis, seperti yang tercantum dalam Penjelasan UUD 1945 sebelum perubahan, makna ketentuan tersebut menurut Mahkamah Konstitusi adalah "Perekonomian berdasar atas demokrasi ekonomi, kemakmuran bagi semua orang. Sebab itu cabang-cabang produksi yang penting bagi negara dan yang menguasai hajat hidup orang banyak harus dikuasai oleh negara. Kalau tidak, tampuk produksi jatuh ke tangan orang-seorang yang berkuasa dan rakyat yang banyak ditindasinya. Hanya perusahaan yang tidak menguasai hajat hidup orang banyak boleh di tangan orang-seorang". Uraian di atas masih menyisakan pertanyaan, apa saja yang termasuk cabang produksi yang penting bagi negara dan yang menguasai hajat hidup orang banyak, serta apa pula makna dikuasai oleh negara itu? ${ }^{46}$

Lebih lanjut, Mahkamah Konstitusi menimbang bahwa dengan memandang UUD 1945 sebagai sistem, maka pengertian "dikuasai oleh negara" dalam Pasal 33 UUD 1945 mengandung pengertian yang lebih tinggi atau lebih luas daripada pemilikan dalam konsepsi hukum perdata. Konsepsi penguasaan oleh negara merupakan konsepsi hukum publik yang berkaitan dengan prinsip kedaulatan rakyat yang dianut dalam UUD 1945, baik di bidang politik (demokrasi politik) maupun ekonomi (demokrasi ekonomi). Dalam paham kedaulatan rakyat itu, rakyatlah yang diakui sebagai sumber, pemilik dan sekaligus pemegang kekuasaan tertinggi dalam kehidupan bernegara, sesuai dengan doktrin "dari rakyat, oleh rakyat dan untuk rakyat". Dalam pengertian kekuasaan tertinggi tersebut, tercakup pula pengertian kepemilikan publik oleh rakyat secara kolektif. ${ }^{47}$

Jika pengertian kata "dikuasai oleh negara" hanya diartikan sebagai pemilikan dalam arti perdata (privat), maka hal dimaksud, menurut Mahkamah Konstitusi tidak akan mencukupi dalam menggunakan penguasaan itu untuk mencapai tujuan "sebesar-besarnya kemakmuran rakyat", yang dengan demikian berarti amanat untuk "memajukan kesejahteraan umum" dan "mewujudkan suatu keadilan sosial bagi seluruh rakyat Indonesia" dalam Pembukaan UUD 1945 tidak mungkin diwujudkan. Namun demikian, konsepsi kepemilikan perdata itu sendiri harus diakui sebagai salah satu konsekuensi logis penguasaan oleh negara yang mencakup juga pengertian kepemilikan publik oleh kolektivitas rakyat atas sumbersumber kekayaan dimaksud. Pengertian "dikuasai oleh negara" juga tidak dapat diartikan hanya sebatas sebagai hak untuk mengatur, karena hal dimaksud sudah dengan sendirinya melekat dalam fungsi-fungsi negara tanpa harus disebut secara khusus dalam undang-undang dasar. Sekiranyapun Pasal 33 tidak tercantum dalam UUD 1945, sebagaimana lazim di banyak negara yang menganut paham ekonomi liberal yang tidak mengatur norma-norma dasar perekonomian dalam konstitusinya, menurut Mahkamah Konstitusi, sudah dengan sendirinya negara berwenang melakukan fungsi pengaturan. Karena itu, perkataan "dikuasai oleh negara" tidak mungkin direduksi pengertiannya hanya berkaitan dengan kewenangan negara untuk mengatur perekonomian. Oleh karena itu, baik pandangan yang mengartikan perkataan

\footnotetext{
46 Ibid.

47 Ibid.
} 
penguasaan oleh negara identik dengan pemilikan dalam konsepsi perdata maupun pandangan yang menafsirkan pengertian penguasaan oleh negara itu hanya sebatas kewenangan pengaturan oleh negara, keduaduanya ditolak oleh Mahkamah Konstitusi. ${ }^{48}$

Dengan demikian, menurut Mahkamah Konstitusi, perkataan "dikuasai oleh negara" haruslah diartikan mencakup makna penguasaan oleh negara dalam arti luas yang bersumber dan berasal dari konsepsi kedaulatan rakyat Indonesia atas segala sumber kekayaan "bumi dan air dan kekayaan alam yang terkandung di dalamnya", termasuk pula di dalamnya pengertian kepemilikan publik oleh kolektivitas rakyat atas sumbersumber kekayaan dimaksud. Rakyat secara kolektif itu dikonstruksikan oleh UUD 1945 memberikan mandat kepada negara untuk mengadakan kebijakan (beleid) dan tindakan pengurusan (bestuursdaad), pengaturan (regelendaad), pengelolaan (beheersdaad) dan pengawasan (toezichthoudensdaad) untuk tujuan sebesar-besarnya kemakmuran rakyat. Fungsi pengurusan (bestuursdaad) oleh negara dilakukan oleh pemerintah dengan kewenangannya untuk mengeluarkan dan mencabut fasilitas perizinan (vergunning), lisensi (licentie), dan konsesi (concessie). Fungsi pengaturan oleh negara (regelendaad) dilakukan melalui kewenangan legislasi oleh DPR bersama dengan Pemerintah, dan regulasi oleh Pemerintah (eksekutif). Fungsi pengelolaan (beheersdaad) dilakukan melalui mekanisme pemilikan saham (share-holding) dan/atau melalui keterlibatan langsung dalam manajemen Badan Usaha Milik Negara atau Badan Hukum Milik Negara sebagai instrumen kelembagaan melalui mana negara c.q. Pemerintah mendayagunakan penguasaannya atas sumber-sumber kekayaan itu untuk digunakan bagi sebesarbesarnya kemakmuran rakyat. Demikian pula fungsi pengawasan oleh negara (toezichthoudensdaad) dilakukan oleh negara c.q. Pemerintah dalam rangka mengawasi dan mengendalikan agar pelaksanaan penguasaan oleh negara atas cabang produksi yang penting dan/atau yang menguasai hajat hidup orang banyak dimaksud benar-benar dilakukan untuk sebesar-besarnya kemakmuran seluruh rakyat. ${ }^{49}$

Dalam kerangka pengertian yang demikian itu, Mahkamah Konstitusi beropini, penguasaan dalam arti kepemilikan perdata (privat) yang bersumber dari konsepsi kepemilikan publik berkenaan dengan cabang-cabang produksi yang penting bagi negara dan/atau yang menguasai hajat hidup orang banyak yang menurut ketentuan Pasal 33 ayat (2) dikuasai oleh negara, tergantung pada dinamika perkembangan kondisi masingmasing cabang produksi. Yang harus dikuasai oleh negara adalah cabang-cabang produksi yang dinilai penting bagi negara dan/atau yang menguasai hajat hidup orang banyak, yaitu: (i) cabang produksi yang penting bagi negara dan menguasai hajat hidup orang banyak, (ii) penting bagi negara tetapi tidak menguasai hajat hidup orang banyak, atau (iii) tidak penting bagi negara tetapi menguasai hajat hidup orang banyak. Ketiganya harus dikuasai oleh negara dan dipergunakan untuk sebesarbesarnya kemakmuran rakyat. Namun, terpulang kepada Pemerintah bersama lembaga perwakilan rakyat untuk menilainya 
apa dan kapan suatu cabang produksi itu dinilai penting bagi negara dan/atau yang menguasai hajat hidup orang banyak. Cabang produksi yang pada suatu waktu penting bagi negara dan menguasai hajat hidup orang banyak, pada waktu yang lain dapat berubah menjadi tidak penting lagi bagi negara dan tidak lagi menguasai hajat hidup orang banyak. Akan tetapi Mahkamah berwenang pula untuk melakukan penilaian dengan mengujinya terhadap UUD 1945 jika ternyata terdapat pihak yang merasa dirugikan hak konstitusionalnya karena penilaian pembuat undang-undang tersebut. ${ }^{50}$

Kemudian Mahkamah Konstitusi berpendapat, jikalau cabang produksi listrik sungguh-sungguh dinilai oleh Pemerintah bersama DPR telah tidak lagi penting bagi negara dan/atau menguasai hajat hidup orang banyak, maka dapat saja cabang itu diserahkan pengaturan, pengurusan, pengelolaan, dan pengawasannya kepada pasar. Namun, jikalau cabang produksi dimaksud masih penting bagi negara dan/atau masih menguasai hajat hidup orang banyak, maka negara c.q. Pemerintah tetap diharuskan menguasai cabang produksi yang bersangkutan dengan cara mengatur, mengurus, mengelola, dan mengawasinya agar sungguh-sungguh dipergunakan untuk sebesar-besarnya kemakmuran rakyat. Di dalam pengertian penguasaan itu tercakup pula pengertian kepemilikan perdata sebagai instrumen untuk mempertahankan tingkat penguasaan oleh negara c.q. Pemerintah dalam pengelolaan cabang produksi listrik dimaksud. Dengan demikian, konsepsi kepemilikan privat oleh negara atas saham dalam badan-badan usaha yang menyangkut cabang-cabang produksi yang penting bagi negara dan/atau menguasai hajat hidup orang banyak tidak dapat didikotomikan ataupun dialternatifkan dengan konsepsi pengaturan oleh negara. Keduanya tercakup dalam pengertian penguasaan oleh negara. Oleh sebab itu, negara tidak berwenang mengatur atau menentukan aturan yang melarang dirinya sendiri untuk memiliki saham dalam suatu badan usaha yang menyangkut cabangcabang produksi yang penting bagi negara dan/atau yang menguasai hajat hidup orang banyak sebagai instrumen atau cara negara mempertahankan penguasaannya atas sumber-sumber kekayaan dimaksud untuk tujuan sebesar-besarnya kemakmuran rakyat. $^{51}$

Akhirnya, Mahkamah Konstitusi memberi pertimbangan bahwa untuk menjamin prinsip efisiensi berkeadilan sebagaimana dimaksud dalam Pasal 33 ayat (4) UUD 1945, yang menyatakan, "perekonomian nasional diselenggarakan berdasar atas demokrasi ekonomi dengan prinsip kebersamaan, efisiensi berkeadilan, berkelanjutan, berwawasan lingkungan, kemandirian, serta dengan menjaga keseimbangan kemajuan dan kesatuan ekonomi nasional", maka penguasaan dalam arti pemilikan privat itu juga harus dipahami bersifat relatif dalam arti tidak mutlak selalu harus $100 \%$, asalkan penguasaan oleh negara c.q. Pemerintah atas pengelolaan sumber-sumber kekayaan dimaksud tetap terpelihara sebagaimana mestinya. Meskipun Pemerintah hanya memiliki saham mayoritas relatif, asalkan tetap menentukan dalam proses pengambilan keputusan atas penentuan kebijakan dalam 
badan usaha yang bersangkutan, maka divestasi ataupun privatisasi atas kepemilikan saham Pemerintah dalam badan usaha milik negara yang bersangkutan tidak dapat dianggap bertentangan dengan Pasal 33 UUD 1945. Dengan demikian, Mahkamah Konstitusi berpendapat, ketentuan Pasal 33 UUD 1945 tidaklah menolak privatisasi, sepanjang privatisasi itu tidak meniadakan penguasaan negara c.q. Pemerintah untuk menjadi penentu utama kebijakan usaha dalam cabang produksi yang penting bagi negara dan/atau menguasai hajat hidup orang banyak. Pasal 33 UUD 1945 juga tidak menolak ide kompetisi di antara para pelaku usaha, sepanjang kompetisi itu tidak meniadakan penguasaan oleh negara yang mencakup kekuasaan untuk mengatur (regelendaad), mengurus (bestuursdaad), mengelola (beheersdaad), dan mengawasi (toezichthoudensdaad) cabang-cabang produksi yang penting bagi negara dan/atau yang mengusai hajat hidup orang banyak untuk tujuan sebesar-besarnya kemakmuran rakyat. ${ }^{52}$

Putusan 001-021-022/PUU-I/2003 yang kemudian dikuatkan dan dikutip kembali oleh 74/PUU-VIII/2010 dapat memberi batasan bagi pengaturan terhadap pelayaran dan maritim khususnya terkait dengan konsepsi penguasaan negara. Mahkamah Konstitusi secara tegas menyatakan, Pasal 33 UUD 1945 tidak menolak ide kompetisi di antara para pelaku usaha, sepanjang kompetisi itu tidak meniadakan penguasaan oleh negara.

\section{Penutup}

Putusan Mahkamah Konstitusi Nomor 74/ PUU-VIII/2010 terkait uji konstitusionalitas
UU Pelayaran sangat penting untuk dalam rangka pembangunan hukum di bidang maritim. Putusan tersebut tidak hanya berbicara terkait dengan satu isu pelayaran semata, tetapi bahkan melebar pada isu hukum dan politik lainnya, yaitu: Pasal 90 ayat (3) huruf g UU Pelayaran merupakan ketentuan yang menyebutkan salah satu jenis kegiatan pengusahaan di pelabuhan tanpa sama sekali menyebutkan subjek hukum yang boleh atau tidak boleh melakukan kegiatan tersebut. Penyebutan jenis kegiatan demikian tidaklah memiliki masalah konstitusionalitas karena tidak ada subjek hukum yang dirugikan maupun diuntungkan dalam penyebutan jenis kegiatan ini. Kemudian terkait dengan penegasan pemaknaan atas diskriminasi dalam konteks hukum, termasuk dalam kaitannya dengan hukum maritim.

Mahkamah Konstitusi secara jelas membatasi dirinya untuk melakukan judicial activism terhadap norma yang bersifat opened legal policy di bidang pelayaran dan maritim. Mahkamah Konstitusi malah melakukan judicial restraint dan berhati-hati untuk tidak masuk ke ranah pembentukan hukum dalam UU Pelayaran.

Terhadap tudingan monopoli dalam UU Pelayaran dan nilai-nilai ekonomis maritim lainnya. Hal ini terkait dengan keberadaan PT. Pelindo yang diberikan hak untuk melakukan kegiatan usaha bongkar muat barang berdasarkan Pasal 90 ayat (3) huruf g UU Pelayaran. Untuk menjawab hal tersebut, Mahkamah Konstitusi menafsirkan Pasal 33 UUD 1945 yang tidak menolak ide kompetisi di antara para pelaku usaha, sepanjang kompetisi tidak meniadakan penguasaan 
oleh negara yang mencakup kekuasaan untuk mengatur (regelendaad), mengurus (bestuursdaad), mengelola (beheersdaad), dan mengawasi (toezichthoudensdaad) cabang-cabang produksi yang penting bagi negara dan/atau yang menguasai hajat hidup orang banyak untuk tujuan sebesar-besarnya kemakmuran rakyat.

Mengingat kompleksitas pembangunan hukum di bidang maritim, maka Putusan Mahkamah Konstitusi Nomor 74/PUUVIII/2010 perlu mendapat perhatian khusus. Pendapat Mahkamah Konstitusi haruslah dijadikan rujukan dalam pembentukan norma dalam hukum maritim dan pelayaran, mengingat konflik norma dan kepentingan sangat rentan untuk diuji. Hal ini penting untuk memberi kepastian hukum yang adil bagi siapapun juga.

\section{Daftar Pustaka}

\section{Buku}

Asshiddiqie, Jimly, Menuju Negara Hukum yang Demokratis, (Jakarta: Setjen dan Kepaniteraan MK RI, 2008).

Eddyono, Luthfi Widagdo, Memaknai Konstitusionalisme Indonesia, (Bandar Lampung: Aura Publishing, 2018).

Konstitusi, Mahkamah, Mengawal Daulat Rakyat; Laporan Tahunan Mahkamah Konstitusi 2018, (Jakarta: Kepaniteraan dan Sekretariat Jenderal MKRI, 2019).

Rachman, Irfan Nur, Konstruksi Pseudo Judicial Review dalam Sengketa Hasil Pemilihan Kepala Daerah, Bandar Lampung: Aura Publishing, 2019).

Soekanto, Sarjono dan Mamudji, Sri, Penelitian Hukum Normatif, Suatu Tinjauan Singkat, (Jakarta: Rajawali Pers, 2008).

\section{Makalah/Artikel/Prosiding/Laporan/Hasil Penelitian}

Wibowo, Mardian, "Menakar Konstitusionalitas sebuah Kebijakan Hukum Terbuka dalam
Pengujian Undang-Undang", Jurnal Konstitusi, Volume 12, Nomor 2, Juni 2015.

\section{Internet}

Pan Mohamad Faiz, "Judicial Restraint vs Judicial Activism", [https://panmohamadfaiz. com/2017/12/31/judicial-restraint-vsjudicial-activism/\#more-1833], diakses 1 April 2019.

[ h t t p : / / m a h pel.d e phub. go.id/_uploads/peraturan / a64fc7d7c223ff44d471ba8ea1efd516.pdf], diakses 1 April 2019.

[http://simpp.mkri.go.id/index.php?page=web. CetakUndangAdv\&id=1\&aw $=1 \& a k=1 \& \mathrm{t} 1=$ pela yaran\&t2=\&t3=\&op1=AND\&op2=AND\&jp1=h. undang_undang\&jp2=a.judul_perkara\&jp $3=a$. judul_perkara\&jmln=0\&st=1], diakses 1 April 2019.

[https://mkri.id/public/content/persidangan/ putusan/putusan_sidang_74\%20PUU\%20 2010_telah\%20BACA.pdf], diakses 1 April 2019.

[https://kbbi.kemdikbud.go.id/entri/ diskriminasi], diakses 1 April 2019.

[ h t t p s: / / w w w.kom n a ham.go.id / files/1475231326-deklarasi-universal-hakasasi--\$R48R63.pdf], diakses 1 April 2019.

[http://hukum.unsrat.ac.id/uu/mpr_17_98.htm], diakses 1 April 2019.

[http://hukum.unsrat.ac.id/uu/uu_39_99.htm], diakses 1 April 2019.

[https://mkri.id/public/content/persidangan/ putusan/Putusan001PUUI2003.pdf], diakses 1 April 2019.

[https://kominfo.go.id/index.php/content/ detail/4327/Presiden+Jokowi+Resmi+Bentuk +Badan+Keamanan+Laut/0/berita], diakses 5 Mei 2019.

\section{Putusan Mahkamah Konstitusi}

Putusan Nomor 001-021-022/PUU-I/2003.

Putusan Nomor 74/PUU-VIII/2010.

Putusan Nomor 65/PUU-XII/2014.

Putusan Nomor 64/PUU-XIII/2015. 